\title{
First Evidence of Fungal Strains Isolated and Identified from Naphtha Storage Tanks and Transporting Pipelines in Venezuelan 0il Facilities
}

\author{
Leopoldo Naranjo, Beatriz Pernía, Ysvic Inojosa, Diego Rojas, Lucia Sena D’Anna, \\ Meralys González, Ángela De Sisto \\ Área de Energía y Ambiente, Instituto de Estudios Avanzados (IDEA), Caracas, Venezuela \\ Email: Inaranjo@idea.gob.ve, lenaranjo@gmail.com
}

Received 22 January 2015; accepted 10 February 2015; published 12 February 2015

Copyright (C) 2015 by authors and Scientific Research Publishing Inc.

This work is licensed under the Creative Commons Attribution International License (CC BY).

http://creativecommons.org/licenses/by/4.0/

c) (i)

\section{Abstract}

Biocorrosion, as well as the biodeterioration of crude oil and its derivatives, is one of the major environmental, operational and economic problems in the Venezuelan oil industry. Fungal contaminants are able to produce large quantities of biomass and synthesize peroxides and organic acids, causing severe damage on metal surfaces and promoting the contamination and biodeterioration of fuels. No evidences regarding fungal strains have been reported to be associated to petroleum naphtha, widely used as a diluent of extra heavy crude oil (EHCO) in the exploitation processes of the Orinoco Oil Belt, the biggest proven reserve of EHCO worldwide. The aims of this paper were to isolate and identify fungal strains from the naphtha storage tank and the naphtha distribution network from an oil field operator in Venezuela. The results showed the isolation of four different fungal strains. The molecular identification by $28 \mathrm{~S}$ rRNA sequencing and phylogenetic tree analysis allowed us to identify the presence of: 1) a new uncultured Ascomycota fungus species BM-103, with high identity to novel hyphomycetes Noosia banksiae and Sporidesmium tengii, in the naphtha storage tank; 2) two yeasts, Rhodotorula mucilaginosa BM-104 (Phylum Basidiomycota) and Wickerhamia sp. BM-105 (Phylum Ascomycota), in a highly damaged naphtha pipeline branch and; 3) Cladosporium cladosporioides BM-102 (Phylum Ascomycota) in a cluster oil well. DNA fingerprinting analysis using ERIC-PCR primers pairs also allowed us to detect the presence of $R$. mucilaginosa BM-104 right in the access of the studied naphtha system. Interestingly, $R$. mucilaginosa and $C$. cladosporioides were previously reported as predominant fungal contaminants of diesel and jet fuel and of kerosene and fuel storage systems, respectively. This paper represents the first evidence of fungal strains isolated and identified from the naphtha systems in the Venezuelan oil industry. The results obtained are discussed. 
Keywords

Fungi, Biocorrosion, Biodeterioration, Naphtha, Pipelines, Extra Heavy Crude Oil, Orinoco Oil Belt

\section{Introduction}

The electrochemical process where microorganisms initiate, facilitate or accelerate a corrosion reaction on a metal surface is defined as Microbiologically Induced Corrosion (MIC) or biocorrosion. MIC processes on metal surfaces are associated with microorganisms, the products of their metabolic activities such as enzymes, exopolymers, organic and inorganic acids, as well as volatile compounds such as ammonia or hydrogen sulfide $\left(\mathrm{H}_{2} \mathrm{~S}\right)$, causing cathodic and/or anodic reactions on metal surfaces thus altering the electrochemical processes at the biofilms/metal interface [1] [2].

The Fungal Influenced Corrosion (FIC) incidence is based on terms of organic acids produced by their metabolic activities that cause localized damage on a metal surface. Fungi are well-known to produce peroxides and oxalic, formic, citric, propionic, acetic acids, kojic, phenylacetic, indolylacetic, dihydroxydibenzenecarboxylic, glutaconic, 4-hydroxymandelic acids and many others, which are capable of promoting FIC [1]-[4]. There are few references to FIC incidence on the electrochemical behavior of carbon steel, although this is a commonly used engineering material in the construction of fuel storage and distribution systems. Aspergillus fumigatus, isolated from diesel oil storage tank sludge, is able to synthesize metabolites resulting from the degradation of diesel, influencing the corrosive behavior on carbon steel. In this case, propionic acid was identified, among other metabolites, in the water phase from growth assays after 60-day incubation [4]. Alternaria alternata was described as the most active biodegrader of AD0 quality aluminum [5], and Arthrinium phaeospermum, Aspergillus niger and Chrysosporium merdarium fungi were reported as the fungi that affected most actively steel and Al surfaces [2].

MIC is recognized as one of the major problems in the industry. It has been estimated that $40 \%$ of the internal damage in transporting pipeline distribution is attributed to biocorrosion [6]. Currently, in the oil production facilities of Venezuelan oil companies established at the Orinoco Oil Belt "Hugo Chávez Frías" (OOB), the biggest proven reserve of EHCO in the world, the biocorrosion problem is increasing and it constitutes one of the main environmental, occupational, operational and economic problems. Although there are no official costs associated to MIC, these usually include the prevention and maintenance costs, control and mitigation of both MIC and biofouling [1], as well as the common replacement of the damaged pipelines sections, which highly increases the production costs.

On the other hand, the presence of aerobic bacteria and fungi in fuel storage systems increases the content of water in fuel due to microbial degradation of fuels. While some species of microorganisms are able to oxidize the hydrocarbons, others are able to use the formed oxidized products, finally transforming these into water, carbon dioxide, methane, $\mathrm{H}_{2} \mathrm{~S}$, pitches and pyrobitumen, producing an unfavorable change in the structures and quality of fuels [6] [7]. In addition, biosurfactant-producing microorganisms lead to fuel emulsification, increasing the microbial penetration into the hydrophobic phase thus biodeterioration of fuels. In this respect, the peroxides and organic acids-producing fungi, apart from promoting FIC, lead to an increase in the viscosity of fuels and to a decrease of its thermal stability and volatility [7].

Fungal contaminants are reported mostly in jet fuel and diesel such as Hormoconis resinae, Aspergillus sp., Penicillium sp. and Fusarium sp. Particularly, the fungus $H$. resinae uses the hydrocarbons of fuel to synthesize organic acids, and is able to produce large quantities of biomass in diesel fuel storage tanks, causing severe damage on metal surfaces [1]. Besides the fungal strains mentioned above, other authors report fungi contaminating various types of oil fuels during storage, such as Cladosporium, Cephalosporium, Chaetomium, Botrytis, Mucor, Trichoderma, Phoma, Rhinocladiella, Rhizopus, Ulocladium, Paecilomyces, Acremonium, Alternaria, and the yeasts Candida, Saccharomyces, Hansenula, Aureobasidium and Rhodotorula [7]. Aspergillus fumigatus, Hormoconis resinae and Candida silvicola were isolated from diesel oil storage tank, being able to degrade this hydrocarbon, especially its aliphatic fractions [4].

Interestingly, our results show for the first time Rhodotorula mucilaginosa and Cladosporium cladosporioides as fungal contaminants of petroleum naphtha. Naphtha is widely used as a diluent of EHCO in the exploitation 
processes of the $\mathrm{OOB}$ and is defined as the fraction of hydrocarbons in petroleum, boiling between $30^{\circ} \mathrm{C}$ and $200^{\circ} \mathrm{C}$. It consists of a complex mixture of hydrocarbon molecules, generally holding between 5 and 12 carbon atoms, and it is used primarily as feedstock for producing high octane gasoline (via the catalytic reforming process). It is also used in the bitumen mining industry as a diluent, in the petrochemical industry for producing olefins in steam crackers, and in the chemical industry for solvent (cleaning) applications [8].

Utilization of molecular and metagenomic techniques to identify specific groups of microorganisms involved into MIC and biodeterioration of fuel will allow a better understanding of the organization of the microbial community implicated in these processes [9]. Control methods should be developed based on the combined information of the material characteristics, the environmental conditions, the operation and maintenance applied to the systems, and the microbial species composition. Due to this, the aims of this paper were to isolate and molecularly identify fungal strains from the naphtha storage tank and the naphtha transporting pipeline distribution from a Venezuelan oil field operator located at the OOB.

\section{Material and Methods}

\subsection{Isolation of Fungal Strains from the Naphtha System}

The studied naphtha distribution system is located in San Diego de Cabrutica, Anzoátegui State, Junín block of the OOB at the Bolivarian Republic of Venezuela (coordinates: 20 p 0284765/0927229). As shown in Figure 1, for filamentous fungi and yeast isolation, the samples were taken in the following hot spots: the naphtha storage tank (inside); the naphtha outlet storage tank; a damaged naphtha pipeline with high criticality levels named T2 B; a damaged naphtha pipeline with high criticality levels named T3 LA; the HC cluster oil wells and; the MC cluster oil wells.

Samples from a water well and hydrostatic test water were taken as control. A duplicate tube with the same culture medium was opened at the same place and moment where the samples were taken to exclude environmental contamination. Also, samples from naphtha inlet storage tank were taken. Power medium (Pw) was used to isolate the fungal strains in axenic culture supplemented with the following antibiotics: tetracycline (0.005 $\mathrm{g} / \mathrm{mL})$, chloramphenicol $(0.034 \mathrm{~g} / \mathrm{mL})$, kanamycin $(0.01 \mathrm{~g} / \mathrm{mL})$, streptomycin $(0.0162 \mathrm{~g} / \mathrm{mL})$ and ampicillin

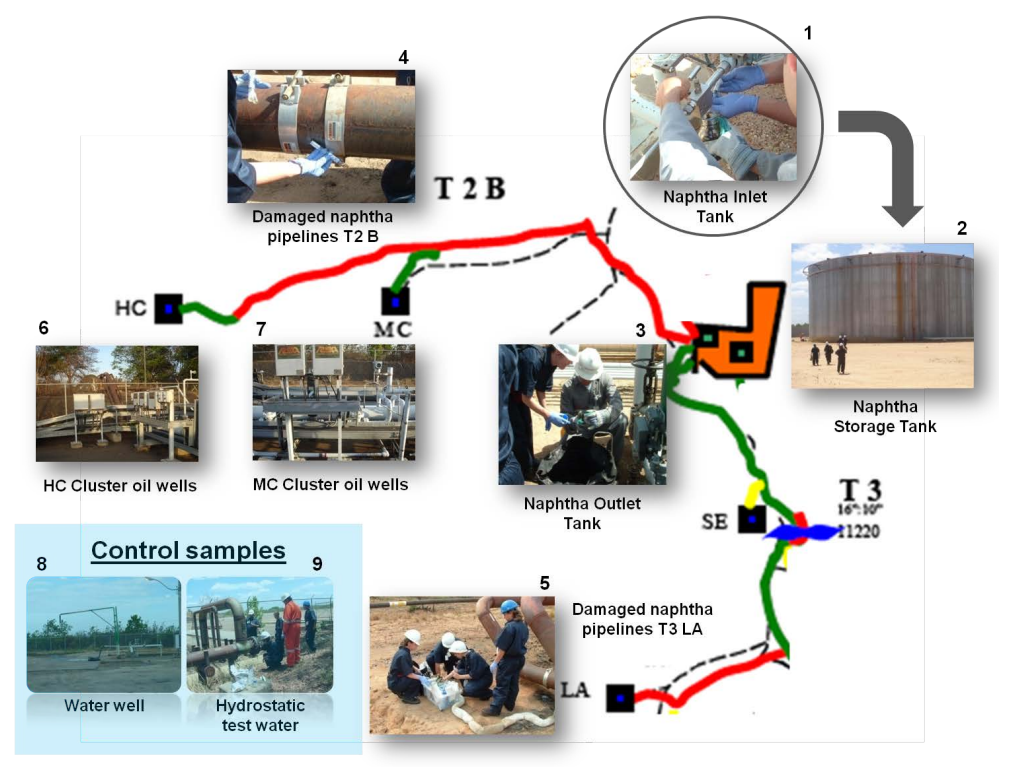

Figure 1. The naphtha distribution system studied. The samples were taken from the naphtha inlet storage tank (1), naphtha storage tank (2), naphtha outlet storage tank (3), in two damaged naphtha pipelines with high criticality levels (T2 B and T3 LA branch; 4 and 5 respectively) and, two cluster oil wells (HC and MC; 6 and 7 respectively). Samples from a water well (8) and hydrostatic test water (9) were taken as control. Red color indicates high criticality level at the T2 B and T3 LA branches. 
$(0.05 \mathrm{~g} / \mathrm{mL})$. The filamentous fungi and yeast strains are preserved in the Culture Collection of Energy and Environmental Area at IDEA under deposit number BM-102, BM-103, BM-104 and, BM-105, respectively.

\subsection{Molecular Identification of Filamentous Fungi and Yeast Strains}

Filamentous fungi and yeast strains were identified through PCR amplification and sequencing of the 28S ribosomal RNA gene. Genomic DNA isolation and PCR amplifications were performed following the protocol described previously by [10] and [11], respectively. PCR conditions consisted of an initial denaturation at $95^{\circ} \mathrm{C}$ for $5 \mathrm{~min}$, and 30 cycles of amplification at $95^{\circ} \mathrm{C}$ for $1 \mathrm{~min}$, annealing at $52^{\circ} \mathrm{C}$ for $1 \mathrm{~min}$, extension at $72^{\circ} \mathrm{C}$ for 1 min, and final extension at $72^{\circ} \mathrm{C}$ for $10 \mathrm{~min}$. The DNA fragment obtained was sequenced using an ABI PrismTM 310 Genetic Analizer (Applied Biosystems, Foster City, Calif.). All other nucleic acid manipulations were performed by standard methods [12]. Nucleotide sequences analysis was carried out using the DNA Base Sequence Assembly Software Version 3.5.3.216 (http://www.dnabaser.com), BLASTN [13] and MycoBank [14].

\subsection{Phylogenetic Tree}

Nucleotide sequences of the 28S rRNA gene were used to perform the phylogenetic tree. The evolutionary history was inferred using the Neighbor-Joining method [15]. The optimal tree with the sum of branch length was 1.19734121. The tree is drawn to scale, with branch lengths in the same units as those of the evolutionary distances used to infer the phylogenetic tree. The evolutionary distances were computed using the Maximum Composite Likelihood method [16], and they are in the units of the number of base substitutions per site. The analysis involved 63 nucleotide sequences. Codon positions included were $1^{\text {st }}+2^{\text {nd }}+3^{\text {rd }}+$ Noncoding. All positions containing gaps and missing data were eliminated. There were a total of 402 positions in the final dataset. Evolutionary analyses were conducted in MEGA5 [17].

\subsection{DNA Fingerprinting Analysis of Rhodotorula Strains}

The determination of genetic diversity among yeast strains was performed by the DNA fingerprinting technique using the ERIC-PCR primers pairs: ERIC-1R (5'-ATGTAAGCTCCTGGGGATTCAC-3') and ERIC-2 (5'AAGTAAGTGACTGGGGTGAGCG-3') [18] and 40 ng of DNA as template. The PCR were performed in a thermocycler Thermal Cycler 2720 (Applied Biosystems, USA) and consisted of a pre-denaturation step at $95^{\circ} \mathrm{C}$ for 5 min followed by 30 cycles of amplification, consisting of the following steps: 1) denaturation at $95^{\circ} \mathrm{C}$ for $30 \mathrm{~s}, 2$ ) annealing at $50^{\circ} \mathrm{C}$ for $30 \mathrm{~s}$; 3) extension at $72^{\circ} \mathrm{C}$ for $6 \mathrm{~min}$, and 4) final extension at $72^{\circ} \mathrm{C}$ for $6 \mathrm{~min}$. For visualization of DNA bands and subsequent genetic discrimination, a Dual-Intensity (USA UVB) transilluminator coupled to an Electrophoresis Documentation Analysis System 120 (Kodak Digital Science) was used. Once the genotype of yeast strains were discriminated, 28S rRNA gene amplification and sequencing were performed as mentioned above to confirm the results obtained by DNA fingerprinting.

\section{Results and Discussion}

\subsection{A New Uncultured Ascomycota Fungal Species and the Cladosporium, Rhodotorula and Wickerhamia Genus Were Identified in the Studied Naphtha System}

The isolation of cultivable fungal strains was obtained only into the naphtha storage tank (2), the highly damaged naphtha pipelines T2B (4), and the MC cluster oil wells (7) (see Figure 1 and Figure 2). In total, only 4 fungal strains (2 filamentous fungi and 2 yeasts) were isolated from the naphtha storage tanks and the transporting pipelines studied. The results of this first approach, allowed us to know that, at least in 3 of the points studied in the naphtha system, there are filamentous fungi and/or yeasts present. Likewise, from the sample taken in the naphtha inlet storage tank (right in the access of the studied naphtha system), the presence of a cultivable yeast strain was also detected. This experiment was conducted in order to determine whether the isolates inside the naphtha storage tanks and transporting pipelines have an intrinsic relationship with microorganisms that may be present in the access of the studied naphtha system.

The composition of the crude oil and oil products, the presence of bioavailable forms of nitrogen, phosphorus, potassium, magnesium, other microelements and water, as well as other appropriated environmental conditions, 


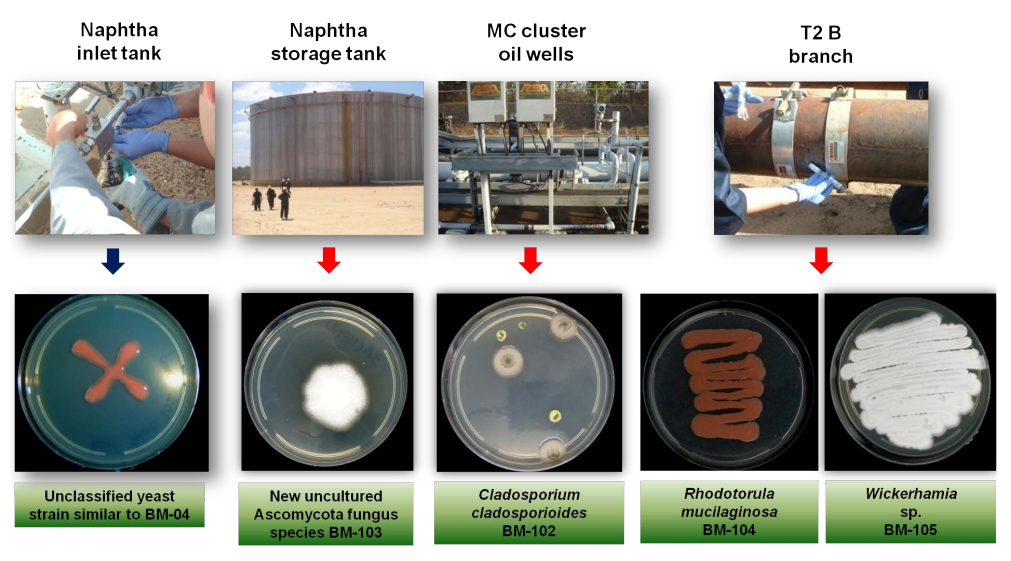

Figure 2. Isolation of yeast and filamentous fungi from the studied naphtha system. Note that unclassified yeast, morphologically identical to $R$. mucilaginosa BM-04, was also isolated from the naphtha inlet storage tank.

such as temperature (from $4^{\circ} \mathrm{C}$ up to $60^{\circ} \mathrm{C}$ ), $\mathrm{pH}$ (from 4 up to 9) and oxygen, induce microbial growth and thus the biofouling processes [7]. It is known that $1 \%$ of water is enough for extensive microbial growth. In fact, fungal spores can survive in the presence of 5 - $80 \mathrm{ppm}$ of water in fuel systems. Besides, the biphasic systems oil/water (o/w) supports the growth of microorganisms in the bottom of tanks, although it is in a fine film of water, where they can use oil as carbon source [7]. Moreover, a significant growth of microorganisms has been observed in the presence of highly salinated water, such as production/formation water (brine) associated to EHCO. Also, even in the presence at $0.1 \mathrm{mg} / \mathrm{L}$ of oxygen, the oxidation/decomposition of hydrocarbons is promoted directly by aerobic microorganisms as well as the formation of slime, biofilms and insoluble particles [7].

Although FIC and fungal degradation of naphtha in the Venezuelan oil industry has not been publicly reported yet, it does not mean that it does not exist. The presence of highly salinated water or brine, oxygen and sediments as contaminants was frequently observed in the studied naphtha distribution systems, besides, a low velocity rate in the pipelines results in water lying in low spots in the line. In fact, all the factors influencing crude oil and oil products biodeterioration are present in their facilities, including a suitable tropical-temperature throughout the year, which makes the storage tanks and the transporting pipeline distribution a great incubator for microorganisms.

In order to molecularly identify the isolated filamentous fungi and yeasts strains, PCR amplification and sequencing of the 28S ribosomal RNA gene were performed. As indicated in Table 1, nucleotide sequences analysis showed the following results: 1) BM-102 strain (GenBank accession number KF611802.1) 100\% of identity to Cladosporium cladosporioides; 2) BM-104 strain (GenBank accession number KF611803.1) 98\% of identity to Rhodotorula mucilaginosa and, 3) BM-105 strain (GenBank accession number KF611804.1) 99\% of identity to Wickerhamia sp. While, 4) the BM-103 strain (GenBank accession number KF611805.1) showed 98\% of identity to Noosia banksiae culture-collection CPC: 17282 (GenBank accession number JF951167.1), and 98\% of identity to Sporidesmium tengii (GenBank accession number DQ408559.1).

However, the nucleotide sequences of the BM-103 strain also showed similarity to several uncultured fungus, such as: uncultured fungus clone FF26 (GenBank accession number AY464861.1) with 97\% of identity; uncultured Periconia clone NG_R_B06 (GenBank accession number GU055658.1) with 97\% of identity, uncultured Ascomycota clone asc07156 (GenBank accession number HQ433102.1) with 96\% of identity, uncultured soil fungus clone NCD_LSU_otu3440 (GenBank accession number KF568410.1) with 96\% of identity and, uncultured soil fungus clone NCD_LSU_otu1274 (GenBank accession number KF566244.1) with 96\% of identity.

In this case, although both DNA sequences of the novel genera of hyphomycetes $N$. banksiae [19] and the novel lignicolous hyphomycetes $S$. tengii [20] showed a high identity (98\%) to the BM-103 strain, DNA sequence, the phylogenetic tree constructed using the Neighbor-Joining method (Figure 3), inferred a clear difference between these two DNA sequences to the BM-103 strain sequence. In fact, while the DNA sequences of $N$. banksiae and S. tengii are grouped in the same cluster, the BM-103 strain nucleotide sequence is located separately from these and one of the rest of studied DNA sequences, which are mainly formed by uncultured fungi. Nevertheless, it is crucial to declare that the taxonomy classification of this fungus in order to strongly establish 
Table 1. GenBank accession number of fungal strains isolated.

\begin{tabular}{cccc}
\hline \multirow{2}{*}{ Strain } & \multicolumn{3}{c}{ GenBank description } \\
\cline { 2 - 4 } & Species & Identity (\%) & GenBank accession number \\
\cline { 2 - 4 } BM-102 & Cladosporium cladosporioides & 100 & KF611802.1 \\
BM-103 & Unculturable new Ascomycota strain ${ }^{\mathrm{a}}$ & 98 & KF611805.1 \\
BM-104 & Rhodotorula mucilaginosa & 98 & KF611803.1 \\
BM-105 & Wickerhamia sp. & 99 & KF611804.1 \\
\hline
\end{tabular}

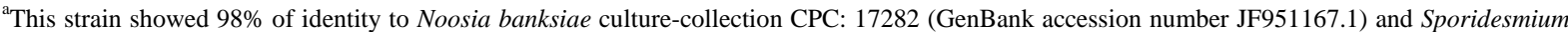
tengii (GenBank accession number DQ408559.1).

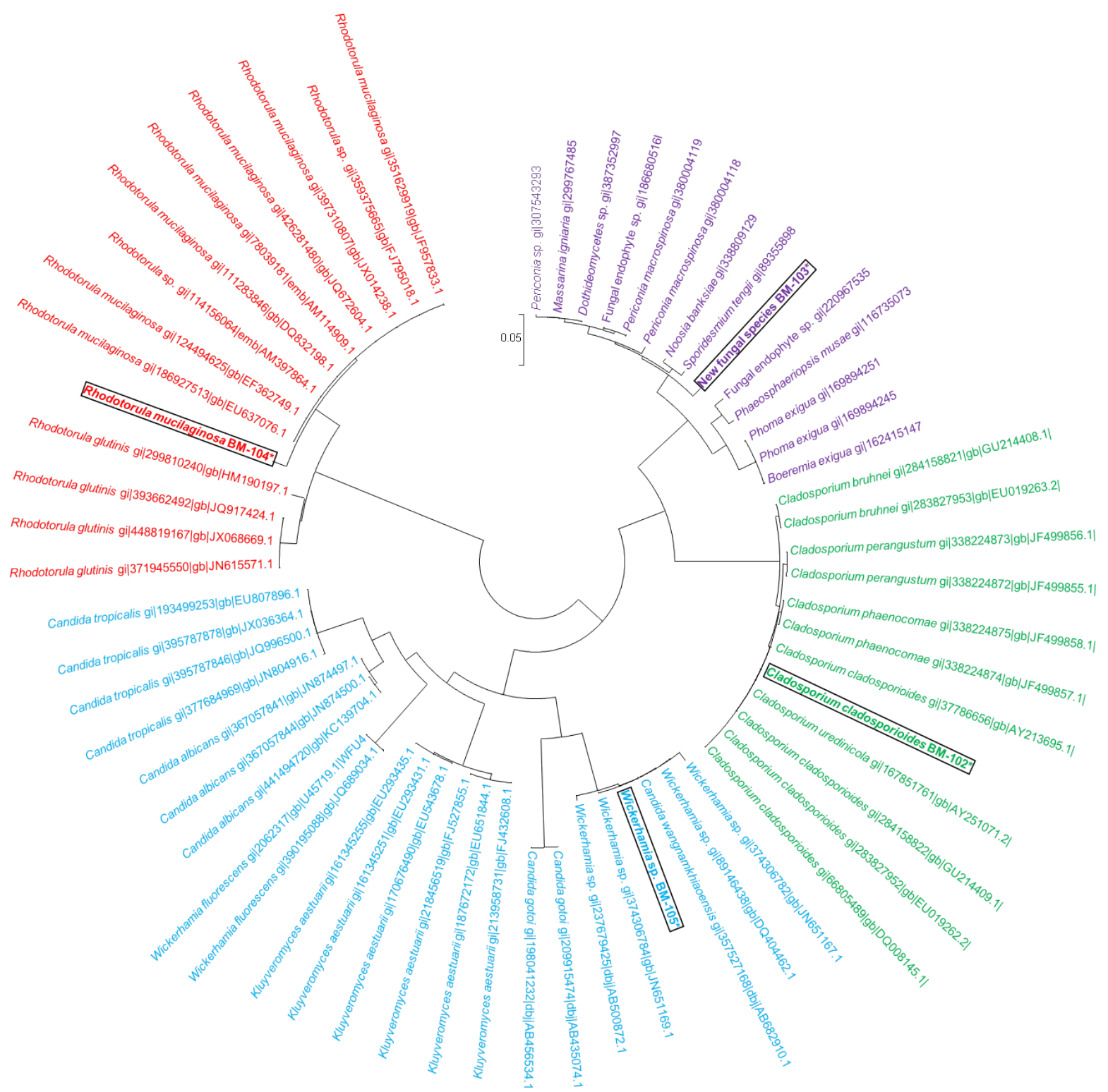

Figure 3. Evolutionary relationships of fungal strains isolated using the Neighbor-Joining method. * Note in green color that C. cladosporioides BM-102 is grouped with other Cladosporium strains of the same species. Blue color indicates that Wickerhamia sp. BM-105 is grouped with other Wickerhamia sp. strains, however, C. wangnamkhiaoensis appears in the same cluster. This is apparently misclassified. Red color shows $R$. mucilaginosa BM-104 grouped with other strains of the same species. Purple color indicates that BM-103 strain is located alone outside, suggested as a new fungal species. 
whether it was a new fungal species was not performed because this strain lost viability and stopped growing in laboratory conditions. These results allow us to suggest that the BM-103 strain corresponds to a new uncultured fungal species.

On the other hand, the BM-105 strain showed 99\% of identity to Wickerhamia sp. ST-122 26S (GenBank accession number DQ404462.1) and to Wickerhamia sp. SSK6 (GenBank accession number AB500872.1); and showed 98\% of identity to Wickerhamia sp. MR73 (GenBank accession number JN651167.1) and to Wickerhamia sp. MR58 (GenBank accession number JN651169.1). Also the BM-105 strain showed 99\% of identity to Candida wangnamkhiaoensis (GenBank accession number AB682910.1), a novel anamorphic yeast species in the Hyphopichia clade isolated in Thailand [21]. However, the phylogenetic tree obtained (Figure 3) inferred a clear difference between the BM-105 strain and C. wangnamkhiaoensis. As you can see in Figure 3, the DNA sequences of Kluyveromyces aestuarii, Candida tropicalis, Candida albicans and Candida gotoi, used as controls, are properly grouped with each other. Moreover, the only two DNA sequences deposited into GenBank corresponding to Wickerhamia fluorescens are grouped together but separately, whereas the nucleotide sequence linked to $C$. wangnamkhiaoensis is grouped in the same cluster formed by DNA sequences of the Wickerhamia species, but is located separately from the DNA sequences of the Candida species, specifically, $C$. tropicalis, $C$. albicans and C. gotoi.

Although the position in the classification of the Wickerhamia genus is similar to the lineage reported for $C$. wangnamkhiaoensis (Division: Ascomycota, Subdivision: Saccharomycotina, Class: Saccharomycetes, Subclass: Saccharomycetidae, Order: Saccharomycetales); from the results obtained by molecular identification, evolutionary relationships between them and according to our preliminary morphological studies, we determine that the BM-105 strain corresponds to the Wickerhamia sp., and not to C. wangnamkhiaoensis, which is assumed to be misreported in the GenBank. However, as the case of the BM-103 strain, the taxonomy classification study was not performed because this strain also lost viability in laboratory conditions.

In the case of the BM-102 strain, nucleotide sequences analysis showed $100 \%$ of identity to C. cladosporioides. This result was confirmed through the phylogenetic tree obtained (Figure 3), which grouped in the same cluster the DNA sequence of the BM-102 strain with the DNA sequences of several C. cladosporioides species reported in the GenBank, except for the DNA sequence linked to C. uredinicola strain CPC 5390 (GenBank accession number AY251071) [22], which is also assumed misreported in the GenBank.

Likewise, the DNA sequences of different species used as control, such as Cladosporium perangustum, Cladosporium phaenocomae and Cladosporium bruhnei, are appropriately grouped in the phylogenetic tree with each other. These results allowed us to determine that the BM-102 strain corresponds to C. cladosporioides.

Finally, the nucleotide sequences analysis of the BM-104 strain showed $98 \%$ of identity to R. mucilaginosa. As you can see in the phylogenetic tree (Figure 3), the DNA sequence of the BM-104 strain was grouped in the same cluster of the DNA sequences of several $R$. mucilaginosa reported in the GenBank. Also, the DNA sequences of some $R$. glutinis used as control were correctly grouped in the same cluster separately. These results strongly indicate that the BM-104 strain corresponds to $R$. mucilaginosa. In this sampling site, the naphtha sample taken was highly contaminated with sediments and water.

Interestingly, unidentified yeast, morphologically identical to R. mucilaginosa, strain BM-04, was also isolated from the naphtha inlet storage tank, right in the access of the studied naphtha system. In this sampling site, the naphtha sample taken was also contaminated with water, sediments and light crude oil (named Mesa crude), also used as a diluent of EHCO to ensure the oil operations in the case of not having naphtha as a diluent in the oil production system. However, at this point of the investigations it was not determined whether the both strains were the same species.

\subsection{R. mucilaginosa BM-104 Was Isolated from the Both Highly Damaged Naphtha Pipeline T2 B Branch and from the Access of the Studied System}

In order to identify if the yeast strain isolated from the naphtha inlet storage tank was the same $R$. mucilaginosa BM-104 species isolated from the highly damaged naphtha pipeline T2 B branch, a DNA fingerprinting analysis using the ERIC-PCR primers pairs was performed. The results showed (Figure 4) that the both isolated were the same strain (line 3 and 4), initially identified as R. mucilaginosa BM-104.

The Enterobacterial Repetitive Intergenic Consensus (ERIC)-PCR method has been widely employed to generate genomic amplification products, numerous microorganisms, including Gram-negative enteric bacteria, 


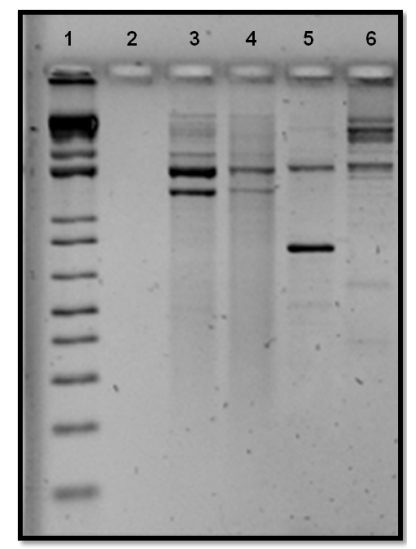

Figure 4. DNA fingerprinting analysis of Rhodotorula strains performed using the ERIC-PCR primers. Line 1 and line 2 corresponds to $1 \mathrm{~Kb}$ Plus DNA Leader molecular weight marker and to reaction control, respectively. Line 5 and line 6 corresponds to the sulfur degrading-bacteria Agrobacterium tumefaciens and Nocardia sp. used as positive control. Note that the yeast strain isolated from the naphtha inlet storage tank (line 4) was the same R. mucilaginosa BM-104 strain (line 3) isolated from the highly damaged naphtha pipelines T2 B branch.

Gram-positive bacteria and related species [18] [23]. Widespread distribution of these repetitive DNA elements in the genomes of various microorganisms should enable rapid identification of bacterial species and strains, and be useful for the analysis of prokaryotic genomes [18].

ERIC-PCR method is frequently employed in our laboratory for studying genetic variability in environmental samples [24]-[28]. Nevertheless, the use of DNA fingerprinting technique with ERIC-PCR primers pairs for studying genetic variability in Rhodotorula strains has not been reported. The genetic variability of environmental isolates of $R$. mucilaginosa using MSP-PCR fingerprinting was described by [29]; however, their results showed that differences were not enough to refute co-specificity. This work represents the first report of genetic discrimination of Rhodotorula strains using ERIC-PCR primers pairs, and is provided as a useful tool for genetic variability studies in this biotechnologically important genus.

\subsection{Spatial Distribution of Main Fungal Strains Isolated from the Studied Naphtha Distribution System}

There are two forms of fungi commonly associated with metal corrosion: the filamentous form and the unicellular form like yeast. Most of these fungi are aerobes and are only found in aerobic habitats, but their spores can survive long periods in adverse growth conditions [3]. The molecular identification of fungal strains isolated from the naphtha storage tank and the transporting pipelines, allowed us to determine a preliminary distribution of the main filamentous fungi and yeast isolated from the sampling sites of the studied naphtha system. Figure 2 shows precisely the isolating site of the microorganims and their molecular identification, while Figure 5 shows a spatial distribution indicating the presence of the diverse genera and species of fungi, which do not repeat from one site to another within the studied system. These results allow us to conclude that a non-identified new Ascomycota fungal species (BM-103) was present only in the naphtha storage tank, the both $R$. mucilaginosa BM-104 and Wickerhamia sp. BM-105 were present in the highly damaged naphtha pipelines T2 B branch and, C. cladosporioides BM-102 was present only in the MC cluster oil wells.

Also, our results (Figure 5) showed that $R$. mucilaginosa BM-104 was also isolated from the naphtha inlet storage tank, suggesting an intrinsic relationship between the microcosms existing in the access point of the naphtha storage tank and inside of the studied naphtha system. In fact, the high tolerance of $R$. mucilaginosa BM-104 to naphtha and its high ability of dispersion in this adverse growth conditions are also suggested. This finding becomes especially important for further studies on $R$. mucilaginosa BM-104.

It is known that fungal spores can survive in a fine film of water in fuel systems. In fact, some fungi can survive in the form of spores in hydrocarbons in the absence of water and germinate when water is available. These fungi can use many organic and inorganic compounds as nutrients and energy sources. In addition to water, other elements are required for growth such as carbon, nitrogen, phosphorus, sulfur and other trace elements. The 


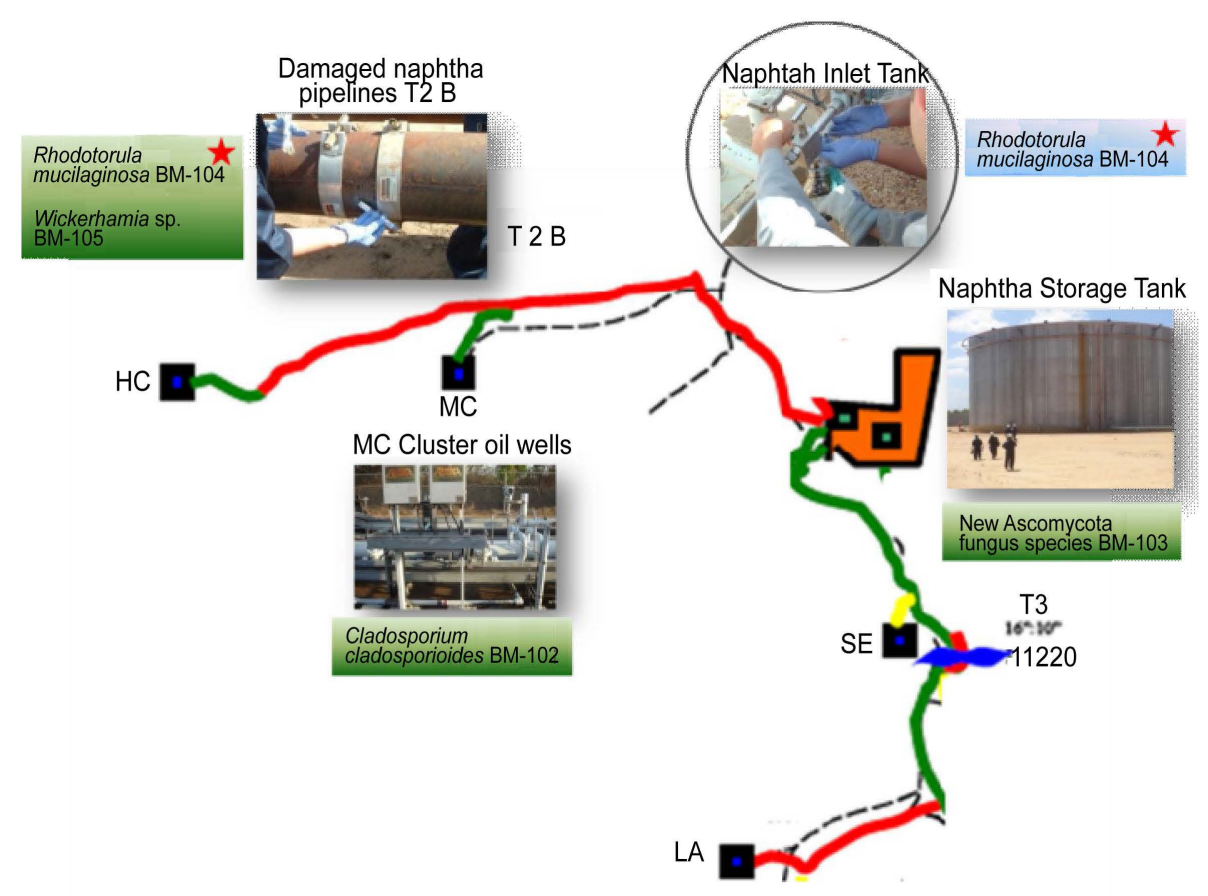

Figure 5. Spatial distribution of yeast and filamentous fungi isolated from the studied naphtha system. A new Ascomycota fungus species BM-103 was isolated only from the naphtha storage tank (inside), R. mucilaginosa BM-104 and Wickerhamia sp. BM-105 were isolated from the highly damaged naphtha pipelines T2 B branch and C. cladosporioides BM-102 was only isolated from cluster oil wells (MC).

first step in fungal decomposition of hydrocarbons requires molecular oxygen and the main products formed are alcohols, aldehydes and aliphatic carboxylic acids [1].

Unexpectedly, the naphtha samples from which Rhodotorula strains were isolated showed contamination of water, sediments or light crude oil, in the case of the sample taken from inlet naphtha storage tank. Also, the presence of oxygen was observed, which promotes the oxidation/decomposition of hydrocarbons as well as the formation of slime, biofilms and insoluble particles [7]. All these conditions are favorable for the growth of microorganisms and were frequently observed. These could explain why R. mucilaginosa BM-104 was present in both of these two equidistant points in the studied naphtha system.

The ability to degrade petroleum hydrocarbons is not restricted to a few microbial genera. Many species of aerobic bacteria, filamentous fungi and yeast can utilize hydrocarbons and its derivatives [7] [30]-[33]. Fungal contaminants are described mostly in jet fuel and diesel, being the main representatives isolates Hormoconis resinae, Aspergillus spp., Penicillium spp. and Fusarium spp., Cladosporium sp., Paecilomyces sp., Candida sp., and Rhodotorula sp. [1] [3] [7] [33].

Interestingly, Rhodotorula species has been identified from condensates of diesel storage systems and a Cladosporium species was reported as contaminant in $85 \%$ of aviation fuel samples tested. Also, Cladosporium has been reported as a predominant contaminant species of kerosene and condensates from systems of fuel storage tank [1]. Although C. cladosporioides and R. mucilaginosa were described as fungal contaminants in fuel/kerosene and diesel, respectively, these genera has not been reported previously as associated to petroleum naphtha. Likewise, Wickerhamia sp. is reported for the first time in the present work as associated to naphtha.

$R$. mucilaginosa [34] is widely found in highly salinated water (e.g. marine water, brine, etc.) and has the following position in classification: Incertae sedis, Sporidiobolales, Incertae sedis, Microbotryomycetes, Pucciniomycotina, Basidiomycota, Fungi. Initially, this species was incorrectly renamed to Rhodotorula rubra but this is not a valid species and the name was reverted to R. mucilaginosa. As shown in the culture plates (Figure 2), the macroscopic morphology colonies are orange to pink to coral and are smooth to rugoid and dull to glistening. The microscopic morphology shows only globose yeast cells with 2 - $5 \mu \mathrm{m}$ in diameter (data not shown).

Recent evidences suggest that aerobically respiring microorganims may protect steel from corrosion. There 
are studies focused on the reduction of carbon steel corrosion in water by uptake of dissolved oxygen using $R$. mucilaginosa. The authors reveled that this strain showed a high uptake of dissolved oxygen (2.8 ppm) as compared to other yeast species. Interestingly, the authors suggested that the use of $R$. mucilaginosa to reduce oxygen corrosion of mild steel in water may solve many problems occurring in cooling towers [35].

\section{Conclusion}

In conclusion, this paper reports for the first time the isolation and identification of $R$. mucilaginosa, C. cladosporioides, Wickerhamia sp. and a new Ascomycota fungus species BM-103 from the naphtha systems in the Venezuelan oil industry. It significantly describes the presence of $R$. mucilaginosa and C. cladosporioides previously reported as predominant fungal contaminants of diesel and jet fuel and of kerosene and fuel storage systems, respectively. On the other hand, this work would be useful for the development of a new approach to molecular detection, monitoring and controlling of MIC/FIC and biodeterioration of crude oil and its derivatives, which should be a strategic challenge for the Venezuelan oil industry and its technical operators, for the petroleum biotechnologists, and also for the selection of suitable biocides, inhibitors and the possible application of advanced proposals of biological control of corrosive and contaminant microorganisms. Our next goals are focused on determining the corrosive potential of the naphtha-tolerant $R$. mucilaginosa BM-04 on coupon carbon steel and its ability to degrade naphtha, and evaluating its potential to uptake of dissolved oxygen to be used as biological control to reduce the MIC in the oil facilities established at the OOB.

\section{Acknowledgements}

This research was supported by the following Researcher Projects: 1) Ministerio del Poder Popular para la Ciencia, Tecnología e Innovación (MppCTI)-FONACIT No. G-2005000440; 2) MppCTI-Misión Ciencia Sub-Proyecto 3 No. 2007001401 and; 3) MppCTI-FONACIT No. G-2011000330. The authors thank Nuñez J., Martínez J., and Rosales J. for technical support, and Naranjo D. and Ascanio A.C. for English grammatical support.

\section{References}

[1] Beech, I. and Gaylarde, C. (1999) Recent Advances in the Study of Biocorrosion: An Overview. Revista de Microbiología, 30, 177-190. http://dx.doi.org/10.1590/S0001-37141999000300001

[2] Lugauskas, A., Prosycevas, I., Ramanauskas, R., Griguceviciene, A., Selskiene, A. and Pakstas, V. (2009) The Influence of Micromycetes on the Corrosion Behaviour of Metals (Steel, Al) under Conditions of the Environment Polluted with Organic Substances. Material Science, 15, 224-235.

[3] Muthukumar, N., Rajasekar, A., Ponmarriappan, S., Mohanan, S., Maruthamuthu, S., Muralidharan, S., Subramanian, P., Palaniswamy, N. and Raghavan, M. (2003) Microbiologically Influenced Corrosion in Petroleum Product Pipelines-A Review. Indian Journal of Experimental Biology, 41, 1012-1022.

[4] Menezes, B., Boguslava, F., Beech, I., Gaylarde, C., Englert, G. and Muller, I. (2005) Degradation and Corrosive Activities of Fungi in a Diesel-Mild Steel-Aqueous System. World Journal of Microbiology and Biotechnology, 21, 135142. http://dx.doi.org/10.1007/s11274-004-3042-2

[5] Smirnov, V., Belov, D., Sokolova, T., Kuzina, O. and Kartashov, V. (2008) Microbiological Corrosion of Aluminum Alloys. Applied Biochemistry and Microbiology, 44, 192-196. http://dx.doi.org/10.1134/S0003683808020117

[6] Rajasekar, A., Balakrishnan, A., Maruthamuthu, S., Ting, Y.P. and Pattanathu, R. (2010) Characterization of Corrosive Bacterial Consortia Isolated from Petroleum-Product-Transporting Pipelines. Applied Microbiology and Biotechnology, 85, 1175-1188. http://dx.doi.org/10.1007/s00253-009-2289-9

[7] Yemashova, N.A., Murygina, V.P., Zhukov, D.V., Zakharyantz, A.A., Gladchenko, M.A., Appana, V. and Kalyuzhnyi, S.V. (2007) Biodeterioration of Crude Oil and Oil Derived Products: A Review. Reviews in Environmental Science and Bio/Technology, 6, 315-337. http://dx.doi.org/10.1007/s11157-006-9118-8

[8] Prestvic, R., Kjell, M., Knut, G. and Holmen, A. (2004) Compositional Analysis of Naphtha and Reformate. Catalytic Naphtha Reforming. CRC Press, USA.

[9] Dong, J. (2003) Microbiological Deterioration and Degradation of Synthetic Polymeric Materials: Recent Research Advances. International Biodeterioration \& Biodegradation, 52, 68-91.

[10] Barnes, C.W., Szabo, L.J. and Bowersox, V.C. (2009) Identifying and Quantifying Phakopsora pachyrhizi Spores in Rain. Phytopathology, 99, 328-338. http://dx.doi.org/10.1094/PHYTO-99-4-0328

[11] Naranjo, L., Urbina, H., De Sisto, A. and León, V. (2007) Isolation of Autochthonous Non-White Rot Fungi with Po- 
tential for Enzymatic Upgrading of Venezuelan Extra-Heavy Crude Oil. Biocatalysis and Biotransformation, 25, 1-9. http://dx.doi.org/10.1080/10242420701379908

[12] Sambrook, J., Fritsch, E.F. and Maniatis, T. (1989) Molecular Cloning: A Laboratory Manual. 2nd Edition, Cold Spring Harbor Laboratory Press, Cold Spring Harbor.

[13] Altschul, S., Madden, T.L., Alejandro, A.S., Zhang, J., Miller, W. and Lipman, D.J. (1997) A New Generation of Protein Database Search Programs. Nucleic Acids Research, 25, 3389-3402. http://dx.doi.org/10.1093/nar/25.17.3389

[14] Crous, P.W., Gams, W., Stalpers, J.A., Robert, V. and Stegehuis, G. (2004) MycoBank: An Online Initiative to Launch Mycology into the 21st Century. Studies in Mycology, 50, 19-22.

[15] Saitou, N. and Nei, M. (1987) The Neighbor-Joining Method: A New Method for Reconstructing Phylogenetic Trees. Molecular Biology and Evolution, 4, 406-425.

[16] Tamura, K., Nei, M. and Kumar, S. (2004). Prospects for Inferring Very Large Phylogenies by Using the NeighborJoining Method. Proceedings of the National Academy of Sciences, 101, 11030-11035. http://dx.doi.org/10.1073/pnas.0404206101

[17] Tamura, K., Peterson, D., Stecher, G., Nei, M. and Kumar, S. (2011) MEGA5: Molecular Evolutionary Genetics Analysis Using Maximum Likelihood, Evolutionary Distance, and Maximum Parsimony Methods. Molecular Biology and Evolution, 28, 2731-2739. http://dx.doi.org/10.1093/molbev/msr121

[18] Versalovic, J., Koeuth, T. and Lupski, J.R. (1991) Distribution of Repetitive DNA Sequences in Eubacteria and Application to Fingerprinting of Bacterial Genomes. Nucleic Acids Research, 19, 6823-6831. http://dx.doi.org/10.1093/nar/19.24.6823

[19] Crous, P.W., Groenewald, J.Z., Shivas, R.G., Edwards, J., Seifert, K.A., Alfenas, A.C., Alfenas, R.F., Burgess, T.I., Carnegie, A.J., Hardy, G.E., Hiscock, N., Hüberli, D., Jung, T., Louis-Seize, G., Okada, G., Pereira, O.L., Stukely, M.J., Wang, W., White, G.P., Young, A.J., McTaggart, A.R., Pascoe, I.G., Porter, I.J. and Quaedvlieg, W. (2011) Fungal Planet Description Sheets: 69-91. Persoonia, 26, 108-156. http://dx.doi.org/10.3767/003158511X581723

[20] Wu, W.P. and Zhuang, W.Y. (2005) Sporidesmium, Endophragmiella and Related Genera from China. Fungal Diversity Research Series, 15, 1-351.

[21] Limtong, S., Kaewwichian, R., Jindamorakot, S., Yongmanitchai, W. and Nakase, T. (2012) Candida wangnamkhiaoensis sp. nov., an Anamorphic Yeast Species in the Hyphopichia Clade Isolated in Thailand. Antonie van Leeuwenhoek, 102, 23-28. http://dx.doi.org/10.1007/s10482-012-9709-z

[22] Braun, U., Crous, P.W., Dugan, F., Groenewald, J.Z. and De Hoog, G.S. (2003) Phylogeny and Taxonomy of Cladosporium-Like Hyphomycetes, including Davidiella gen. nov., the Teleomorph of Cladosporium s. str. Mycological Progress, 2, 3-18. http://dx.doi.org/10.1007/s11557-006-0039-2

[23] Niemann, S., Dammann-Kalinowski, T., Nagel, A., Pühler, A. and Selbitschka, W. (1999) Genetic Basis of Enterobacterial Repetitive Intergenic Consensus (ERIC)-PCR Fingerprint Pattern in Sinorhizobium meliloti and Identification of S. meliloti Employing PCR Primers Derived from an ERIC-PCR Fragment. Archives of Microbiology, 172, 22-30. http://dx.doi.org/10.1007/s002030050735

[24] León, V., De Sisto, A., Demey, J., Muñoz, S., Ilzins, O., Urbina, H., Luis, L., Tusa, A. and Naranjo, L. (2006) Bioremediation of Crude Oil Contaminated Soils. Bacterial Population Assessment and Evolution in the Time. Proceedings of the 1st International Symposium on Environmental Biocatalysis, Córdoba, 23-26 April 2006.

[25] León, Y., De Sisto, A., Inojosa, Y., Malaver, N. and Naranjo-Briceño, L. (2009) Identificación de biocatalizadores potenciales para la remediación de desechos petrolizados de la Faja Petrolífera del Orinoco. Revista de Estudios Transdisciplinarios (RET), 1, 12-25.

[26] De Sisto, A., Naranjo-Briceño, L., Inojosa, Y., Rojas-Tortolero, D., Sena, L., González, M., Freites, M., Pernía, B., García, D. and Duque, Z. (2010) Caracterización bioquímica y molecular de bacterias planctónicas asociadas a sistemas de distribución de nafta y su implicación en procesos de biocorrosión en instalaciones petroleras. Proceedings of the 2nd Congreso de la Sociedad Latinoamericana de Biotecnología Ambiental y Algal (SOLABIAA), Cancún, 5-9 December 2010.

[27] De Sisto, A., González, M., Inojosa, Y., Perdomo-Játem, T., Rojas Tortolero, D., Naranjo Briceño, L. and Freites, M. (2012) Aislamiento e identificación molecular de bacterias provenientes de suelo impactado con crudo y su potencial uso en Biodesulfuración. Proceedings of the 1st Congreso Venezolano de Ciencia Tecnología e Innovación, Caracas, 23-25 September 2012.

[28] Naranjo-Briceño, L., De Sisto, A., García, D., Duque, Z., Freites, M., Rojas, D., Gonzalez, M., Sena, L., Inojosa, Y., Pernía, B., Fusella, E., Demey, J., Páez, R., Núñez, J. and Urbina, J. (2012) Metagenomics Tools and SEM Applied to Identify Corrosive Microorganims from Naphtha Transporting Pipelines of Venezuelan Oil Industries. Proceedings of BIT's 3rd Annual World Congress of Petroleum Microbiology (WCP-2012), Xi'an, 25-27 April 2012.

[29] Libkind, D., Gadanho, M., van Broock, M. and Sampaio, J.P. (2008) Studies on the Heterogeneity of the Carotenogen- 
ic Yeast Rhodotorula mucilaginosa from Patagonia, Argentina. Journal of Basic Microbiology, 48, 93-98. http://dx.doi.org/10.1002/jobm.200700257

[30] Zobell, C.E. (1946) Action of Microorganism on Hydrocarbons. Bacteriological Reviews, 10, 1-49.

[31] Bartha, R. and Atlas, R.M. (1977) The Microbiology of Aquatic Oil Spills. Advances in Applied Microbiology, 22, 225-226. http://dx.doi.org/10.1016/S0065-2164(08)70164-3

[32] Walker, J.D. and Cooney, J.J. (1973) Pathway of $n$-Alkane Oxidation in Cladosporium resinae. The Journal of Bacteriology, 1152, 635-639.

[33] Pernía, B., Demey, J.R., Inojosa, Y. and Naranjo, L. (2012) Biodiversidad y potencial hidrocarbonoclástico de hongos aislados de crudo y sus derivados: Un meta-análisis. Revista Latinoamericana de Biotecnología Ambiental y Algal, 3 , 1-40.

[34] Harrison, F.C. (1928) Rhodotorula mucilaginosa (Jörgensen). Transactions of the Royal Society of Canada, 22, 187225.

[35] Dabhole, M.P. and Joishy, K.N. (2003) Mild Steel Corrosion Reduction in Water by Uptake of Dissolved Oxygen by Rhodotorula mucilaginosa. Journal of Scientific \& Industrial Research, 62, 683-689. 
Scientific Research Publishing (SCIRP) is one of the largest Open Access journal publishers. It is currently publishing more than 200 open access, online, peer-reviewed journals covering a wide range of academic disciplines. SCIRP serves the worldwide academic communities and contributes to the progress and application of science with its publication.

Other selected journals from SCIRP are listed as below. Submit your manuscript to us via either submit@scirp.org or Online Submission Portal.
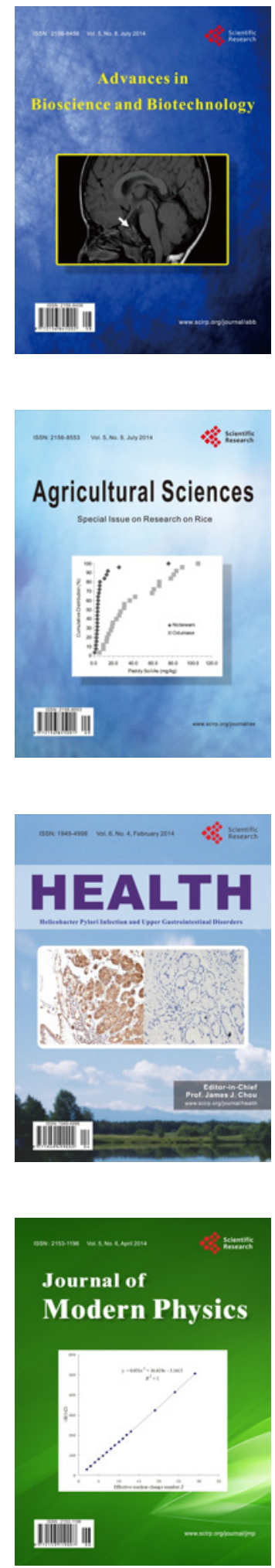
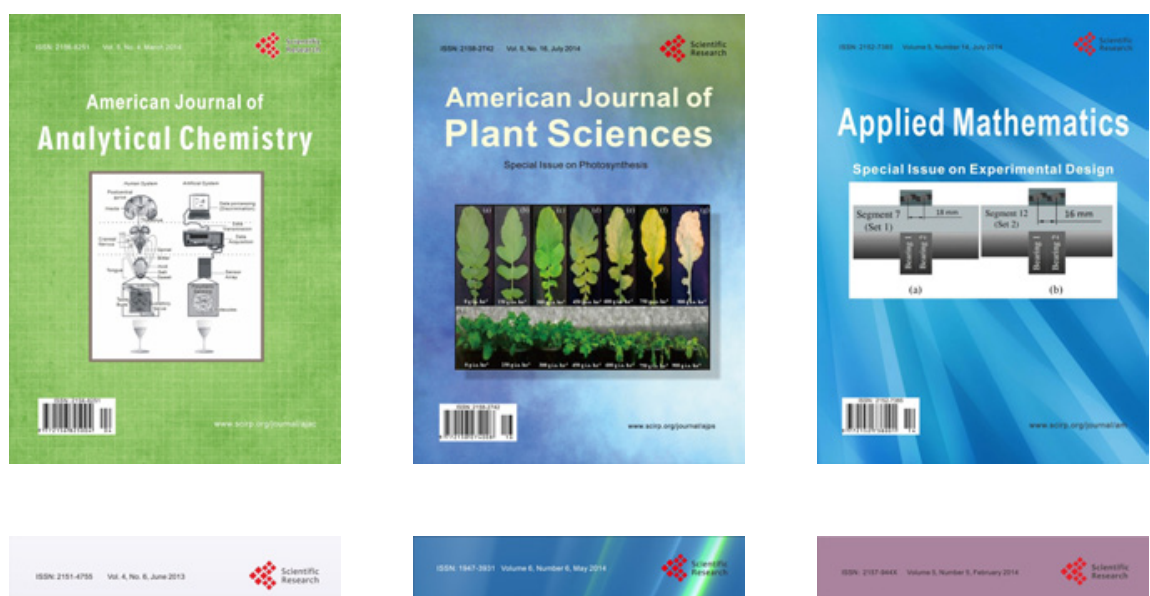

Creative Education
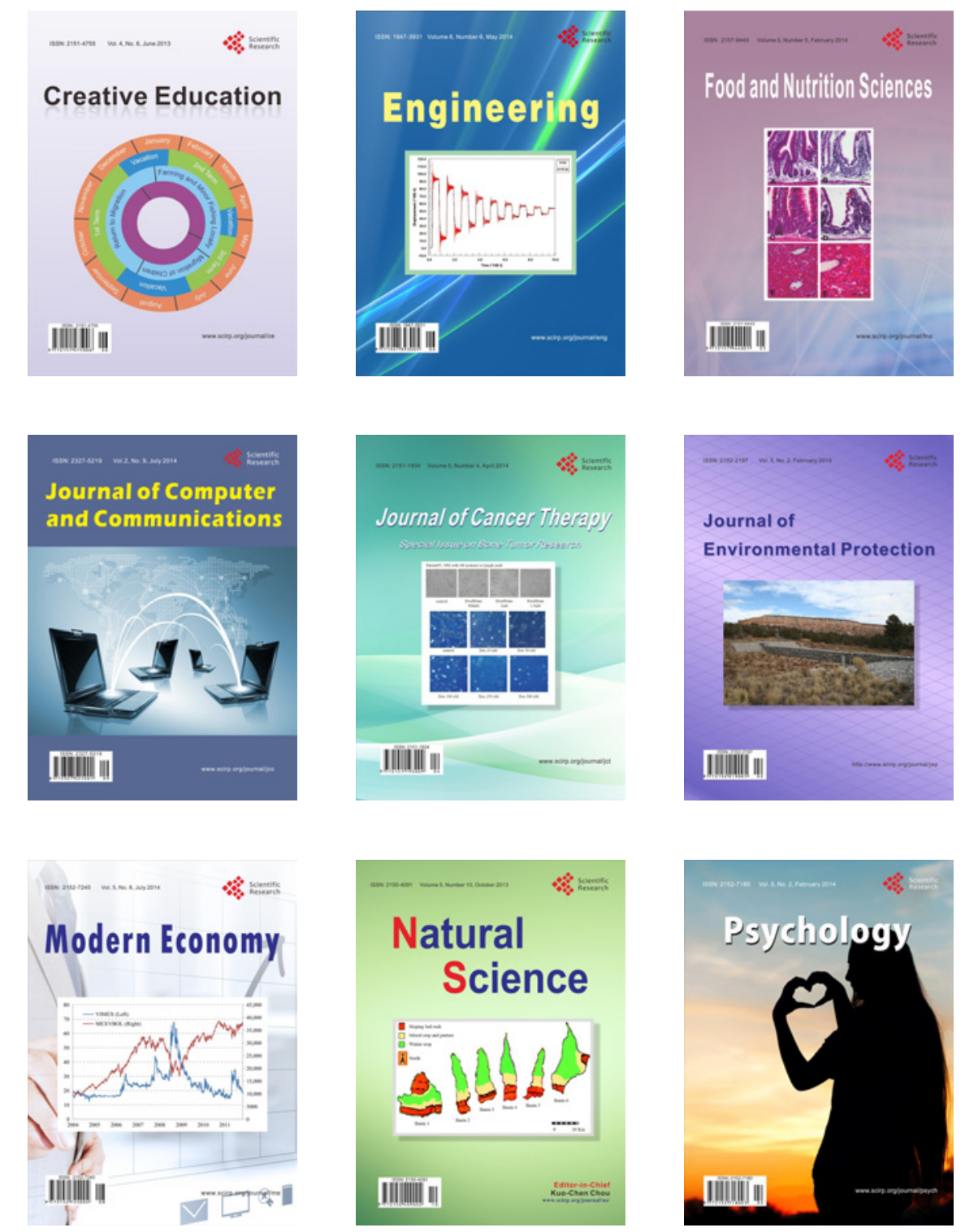